\title{
IMPLEMENTASI MANAJEMEN RESIKO SYARIAH DALAM KOPERASI SYARIAH
}

\author{
Wahyu Hidayat ${ }^{1}$ \\ wahyuhidayat23885@gmail.com
}

\begin{abstract}
The existence of sharia risk management is to guarantee the existence of a Sharia Cooperative in the long run. With sharia risk management, it is expected to be able to provide guidance for the Sharia / Baitul Maal Wa Tamwil Cooperative in implementing sharia risk management in its business operations, especially for cooperatives that are engaged in sharia financial services or known as Sharia Credit and Financing Cooperatives (KSPPS). In any business activity it has the potential to risk. Risk is defined as uncertainty caused by changes. There are various kinds of risks in the operations of sharia cooperatives such as financing risk, liquidity risk, margin, organization, solvency, operational, capital, legal risk and compliance with sharia principles. Risk management is done so that the risk can be minimized to a minimum, so that plans and targets that have

been planned can be realized so as to produce benefit. In the implementation of risk management in Islamic cooperatives can combine SWOT analysis, prudential concept with

$5 C$ and Maqosid Syariah. In principle, every business activity has a risk, but we can minimize the risk to the lowest point if we do it in the right way and according to sharia.
\end{abstract}

Keywords: Risk management; Sharia Cooperative; Maqosid Syariah

\section{Abstrak}

Keberadaan manajemen resiko syariah adalah untuk menjamin eksistensi Koperasi Syariah dalam jangka panjang. Dengan manajemen resiko syariah ini diharapkan mampu

memberikan pedoman bagi Koperasi Syariah/Baitul Maal Wa tamwil didalam mengimplementasikan manajemen resiko syariah pada operasional bisnisnya terutama bagi koperasi yang jenis usaha yang bergerak pada jasa keuangan syariah atau yang dikenal dengan Koperasi Simpan Pinjam dan Pembiayaan Syariah(KSPPS). Dalam setiap aktivitas bisnis berpotensi terhadap resiko. Risiko diartikan sebagai ketidakpastian yang ditimbulkan oleh adanya perubahan. Terdapat berbagai macam resiko dalam operasional koperasi syariah seperti resiko pembiayaan, resiko likuiditas, nilai margin, organisasi, solvabilitas , operasional, capital, resiko hukum dan kepatuhan terhadap prinsip-prinsip syariah. Manajemen resiko dilakukan agar resiko dapat ditekan seminimal mungkin, agar rencana dan target yang telah dicanangkan dapat terealisasi sehingga menghasilkan

${ }^{1}$ Dosen Tetap Prodi Perbankan Syariah STAI Asy-Syukriyyah Tangerang 


\section{Jurnal Asy-Syukriyyah}

kemaslahatan. Didalam implementasi manajemen resiko dalam koperasi syariah dapat mengkombinasikan antara analisis SWOT, konsep prudential dengan 5C dan Maqosid Syariah.

Pada prinsipnya setiap aktifitas bisnis itu memliki resiko, namun resiko dapat kita minimalisir sampai pada titik terendah apabila kita lakukan dengan cara yang tepat dan sesuai syariah.

Kata kunci: Manajemen resiko;Koperasi syariah;Maqosid Syariah

\section{A. Pendahuluan}

Indonesia sebagai Negara dengan penduduk muslim terbesar didunia memiliki potensi pertumbuhan system ekonomi, pelaksanaan sistem ekonomi Islam yang sudah dimulai sejak awal tahun 90 an semakin semarak dengan bertambahnya jumlah lembaga keuangan Islam baik yang bank maupun non bank. Salah satu lembaga keuangan Islam yang non bank adalah Baitul Mal wat Tamwil (BMT) yang berbadan hukum Koperasi dengan prinsip/system syariah bertujuan untuk mensejahterakan anggota dan syiar ekonomi Islam kepada masyarakat luas. Kelahiran BMT merupakan solusi bagi kelompok ekonomi masyarakat bawah yang membutuhkan dana bagi pengembangan usaha kecil. BMT merupakan lembaga ekonomi rakyat kecil yang berupaya mengembangkan usahausaha produktif dan investasi dalam rangka meningkatkan kegiatan ekonomi pengusaha kecil dengan berdasarkan prinsip syariah dan koperasi.

Dalam pandangan Islam, koperasi tergolong sebagai syirkah/syarikah. Lembaga ini adalah wadah kemitraan, kerjasama, kekeluargaan, dan kebersamaan usaha yang sehat, baik, dan halal. Dan, lembaga yang seperti itu sangat dipuji Islam seperti dalam firman Allah, "Dan bekerjasamalah dalam kebaikan dan ketakwaan, dan janganlah saling bekerjasama dalam dosa dan permusuhan." Dan sesuai sabda Rasulullah saw; "Allah akan mengabulkan doa bagi dua orang yang bermitra selama di antara mereka tidak saling mengkhianati." (Al-Bukhari).

Didalam perjalanan bisnisnya BMT mengalami beberapa kendala, diantaranya dalam mengimplementasikan manajemen syariah dalam operasional koperasi syariah 
tersebut. Sehingga diperlukan konsep yang konstruktif agar kendala yang dihadapi Koperasi syariah berkenaan dengan manajemen syariah dapat teratasi.

\section{B. Tinjauan Pustaka}

\section{Definisi Manajemen dan Koperasi Syariah}

Manajemen adalah seni menyelesaikan pekerjaan melalui orang lain. Definisi Mary Parker Follet ini berarti bahwa seorang manajer bertugas mengatur dan mengarahkan orang lain untuk mencapai tujuan organisasi ${ }^{2}$. Ricky W. Griffin mendefinisikan manajemen sebagai sebuah proses perencanaan, pengorganisasian, pengkoordinasian, dan pengontrolan sumber daya untuk mencapai sasaran secara efektif dan efesien. Efektif berarti bahwa tujuan dapat dicapai sesuai dengan perencanaan, sementara efisien berarti bahwa tugas yang ada dilaksanakan secara benar, terorganisir, dan sesuai dengan jadwal ${ }^{3}$. Manajemen belum memiliki definisi yang luas dan diterima secara universal.

Kata Manajemen berasal dari bahasa Perancis kuno ménagement, yang memiliki arti "seni melaksanakan dan mengatur." Dalam bahasa Italia (1561) maneggiare yang berarti "mengendalikan," terutama dalam konteks mengendalikan kuda, yang berasal dari bahasa latin manus yang berarti "tangan".Bahasa Prancis lalu mengadopsi kata ini dari bahasa Inggris menjadi ménagement, yang memiliki arti seni melaksanakan dan mengatur ${ }^{4}$.

Fungsi manajemen adalah elemen-elemen dasar yang akan selalu ada dan melekat di dalam proses manajemen yang akan dijadikan acuan oleh manajer dalam melaksanakan kegiatan untuk mencapai tujuan Fungsi manajemen pertama kali diperkenalkan oleh seorang industrialis Perancis bernama Henry Fayol pada awal abad ke-20. Ketika itu, ia menyebutkan lima fungsi manajemen, yaitu merancang,

\footnotetext{
${ }^{2}$ Vocational Business: Training, Developing and Motivating People by Richard Barrett - Business \& Economics - 2003. - Page 51

${ }^{3}$ Griffin, R. 2006. Business, 8th Edition. NJ: Prentice Hall.

${ }^{4}$ Oxford English Dictionary
} 


\section{Jurnal Asy-Syukriyyah}

mengorganisir, memerintah, mengordinasi, dan mengendalikan. Namun saat ini, kelima fungsi tersebut telah diringkas menjadi tiga, yaitu:

a. Perencanaan (planning) adalah memikirkan apa yang akan dikerjakan dengan sumber yang dimiliki. Perencanaan dilakukan untuk menentukan tujuan perusahaan secara keseluruhan dan cara terbaik untuk memenuhi tujuan itu.

b. Pengorganisasian (organizing) dilakukan dengan tujuan membagi suatu kegiatan besar menjadi kegiatan-kegiatan yang lebih kecil. Pengorganisasian mempermudah manajer dalam melakukan pengawasan dan menentukan orang yang dibutuhkan untuk melaksanakan tugas yang telah dibagi-bagi tersebut.

c. Pengarahan (directing) adalah suatu tindakan untuk mengusahakan agar semua anggota kelompok berusaha untuk mencapai sasaran sesuai dengan perencanaan manajerial dan usaha.

\section{Koperasi Syariah}

BMT merupakan lembaga keuangan yang inklusif, yang melayani berbagai kalangan. Kehadiran BMT menjadi warna tersendiri dalam industri keuangan syariah. Dengan proses yang sederhana, namun tetap berpegang pada prisip kehati-hatian membuat BMT kian digandrungi masyarakat mikro.

Di dalam melakukan pekerjaannya BMT selalu berorientasi dunia-akhirat. Berharap memperoleh kesuksesan masa kini dan akan datang yaitu hari akhir, hari yang lebih baik. Sesuai dengan firman Allah dalam Surah Adh Duha ayat 4: "Dan sesungguhnya hari kemudian itu lebih baik bagimu daripada yang sekarang (permulaan)",

Koperasi syariah mulai diperbincangkan banyak orang ketika menyikapi semaraknya pertumbuhan BMT di Indonesia. BMT dimotori pertamakalinya oleh BMT Bina Insan Kamil di Jakarta tahun 1992, ternyata mampu meberi warna bagi perekonomian kalangan akar rumput yakni para pengusaha mikro ${ }^{5}$

\footnotetext{
${ }^{5}$ Koperasi Syariah: Teori dan Praktik - 2012. - hal.2
} 


\section{Jurnal Asy-Syukriyyah}

Kegiatan BMT atau Baitul Maal wa Tamwil bertujuan profit oriented dan kegiatan social oriented. Bertujuan profit oriented, maka BMT pun harus dijalankan berdasarkan kaidah umum ekonomi, seperti harus mampu menghasilkan pendapatan yang dapat menutup keseluruhan biaya yang diperlukan dalam menjalankan operasional BMT. Ciri khas lainnya dari BMT adalah mempunyai fungsi social oriented. Secara konsepsi BMT adalah suatu lembaga yang didalamnya juga mencakup kegiatan mengumpulkan dana dari berbagai sumber yang penggunaannya untuk kepentingan sosial kemasyarakatan. Dana yang dikumpulkan dan disalurkan BMT diantaranya berupa zakat, infak, shadaqah, hibah, dan wakaf.

\section{Asas Transaksi Syariah}

Dalam masalah transaksi syariah, Ikatan Akuntan Indonesia (IAI) telah merinci bahwa transaksi syariah berasaskan pada prinsip:
a. persaudaraan (ukhuwah);
b. keadilan ('adalah);
c. kemaslahatan (maslahah);
d. keseimbangan (tawazun);
e. universalisme (syumuliyah).

Koperasi syariah secara prinsip diharapkan dapat mengahadirkan kemaslahatan (mashlahah), esensinya merupakan segala bentuk kebaikan dan manfaat yang berdimensi duniawi dan ukhrawi, material dan spiritual, serta individual dan kolektif. Kemaslahatan yang diakui harus memenuhi dua unsur yakni kepatuhan syariah (halal) serta bermanfaat dan membawa kebaikan (thayib) dalam semua aspek-aspek secara keseluruhan yang tidak menimbulkan kemudharatan. Transaksi syariah yang dianggap bermaslahat harus memenuhi secara keseluruhan unsur-unsur yang menjadi tujuan ketetapan syariah (maqasid sya-riah), yaitu berupa pemeliharaan terhadap : 


\section{Jurnal Asy-Syukriyyah}

1. akidah, keimanan dan ketakwaan (hifzu ad-dien);

2. intelek (hifzu al-'aql);

3. keturunan (nasl);

4. jiwa dan keselamatan (hifzu an-nafs), dan

5. harta benda (hifzu al-mal).

Koperasi memiliki standar manajemen usaha yaitu terlaksananya proses usaha KSPPS/USPPS Koperasi sebagai lembaga yang mengelola usaha simpan pinjam dan pembiayaan syariah sehingga dapat berkembang sesuai dengan prinsip koperasi dan prinsip syariah serta dapat mewujudkan visi dan misi yang ditetapkan ${ }^{6}$.

\section{Manajemen Resiko}

Manajemen Risiko adalah seperangkat kebijakan, prosedur yang lengkap yang dimiliki organisasi, untuk mengelola, memonitor, dan mengendalikan eksposur organisasi terhadap risiko. Risiko diartikan sebagai ketidakpastian yang ditimbulkan oleh adanya perubahan.

Risiko adalah penyimpangan dari sesuatu yang diharapkan . Faktor ketidakpastian inilah yang akhirnya menyebabkan timbulnya risiko pada suatu kegiatan. Sedangkan dari sudut pandang bisnis, secara umum risiko dapat didefinisikan sebagai potensi, kemungkinan atau ekspektasi terhadap suatu kejadian yang dapat berpengaruh secara negatif terhadap pendapatan dan modal. Vaughan (1978) mengemukakan beberapa definisi risiko adalah "kans kerugian biasanya digunakan untuk menunjukkan suatu keadaan dimana terdapat suatu keterbukaan terhadap kerugian atau suatu kemungkinan kerugian".

${ }^{6}$ Deputi Bidang Pembiayaan.2015. Penyempurnaan Pedoman Standar Operasional Manajemen KJKS/UJKS koperasi. Jakarta: Kementrian Koperasi dan Usaha Kecil Menengah Republik Indonesia. hal.39 


\section{Jurnal Asy-Syukriyyah}

a. Tujuan Manajemen Risiko

Ada beberapa yang menjadi tujuan dalam penerapan manajemen risiko yang diyakini mampu untuk :

1) memastikan risiko-risiko yang ada diperusahaan telah identifikasi dan dinilai, serta telah dibuatkan rencana tindakan untuk meminimalisasi dampak dan kemungkinan terjadinya.

2) memastikan bahwa rencana tindakan telah dilaksanakan secara efektif dan dapat meminimalisasi dampak dan kemungkinan terjadinya risiko.

3) meningkatkan efektivitas dan efisiensi manajemen karena semua risiko yang dapat menghambat proses perusahaan telah diidentifikasikan dengan baik, termasuk cara untuk mengatasi gangguan kelancaran proses perusahaan telah diantisipasi sebelumnya sehingga jika gangguan tersebut terjadi, perushaan telah siap untuk menanganinya dengan baik.

4) membantu manajemen perusahaan dalam pengambilan keputusan dengan menyediakan informasi mengenai risiko-risiko yang ada di perusahaan, baik risiko strategis maupun kegiatan fungsi-fungsi/proses bisnis di unit kerja.

5) lebih memberikan jaminan yang wajar atas pencapaian sasaran perusahaan karena terselenggaranya manajemen yang lebih efektif dan efisien, hubungan dengan pemangku kepentingan yang semakin membaik, kemampuan menangani risiko perusahaan yang juga meningkat, termasuk risiko kepatuhan dan hukuman.

b. Fungsi Manajemen Risiko

Fungsi manajemen risiko sering diterjemahkan dalam tiga langkah, yaitu perencanaan, pelaksanaan, dan pengendalian:

1) Perencanaan

Perencanaan manajemen risiko dapat dimulai dengan menetapkan visi, misi, tujuan yang berkaitan dengan manajemen risiko. Kemudian, perencanaan 


\section{Jurnal Asy-Syukriyyah}

manajemen risiko dapat dilanjutkan dengan penetapan target, kebijakan dan prosedur yang berkaitan dengan manajemen risiko. Akan lebih baik lagi jika visi, misi, kebijakan, dan prosedur tersebut dituangkan secara tertulis untuk memudahkan pengarahan, sekaligus menegaskan dukungan manajemen terhadap program manajemen risiko.

2) Pelaksanaan

Pelaksanaan manajemen risiko meliputi aktivitas operasional yang berkaitan dengan manajemen risiko .Proses identifikasi dan pengukuran risiko diteruskan dengan manajemen (pengelolaan) risiko yang merupakan aktivitas operasional yang utama dari manajemen risiko, sebagai berikut:

a) Identifikasi risiko, dilkakukan untuk mengidentifikasi risiko-risiko yang dihadapi oleh organisasi

b) Evaluasi dan pengukuran risiko, memahami karakteristik risiko dengan lebih baik.

c) Pengelolaan Risiko harus dikelola, karena jika organisasi gagal mengelola konsekuensi yang diterima cukup besar.

3) Pengendalian

Meliputi evaluasi secara periodik pelaksanaan manajemen risiko, outputpelaporan yang dihasilkan oleh manajemen risiko dan umpan balik.

\section{Manajemen risiko Syariah}

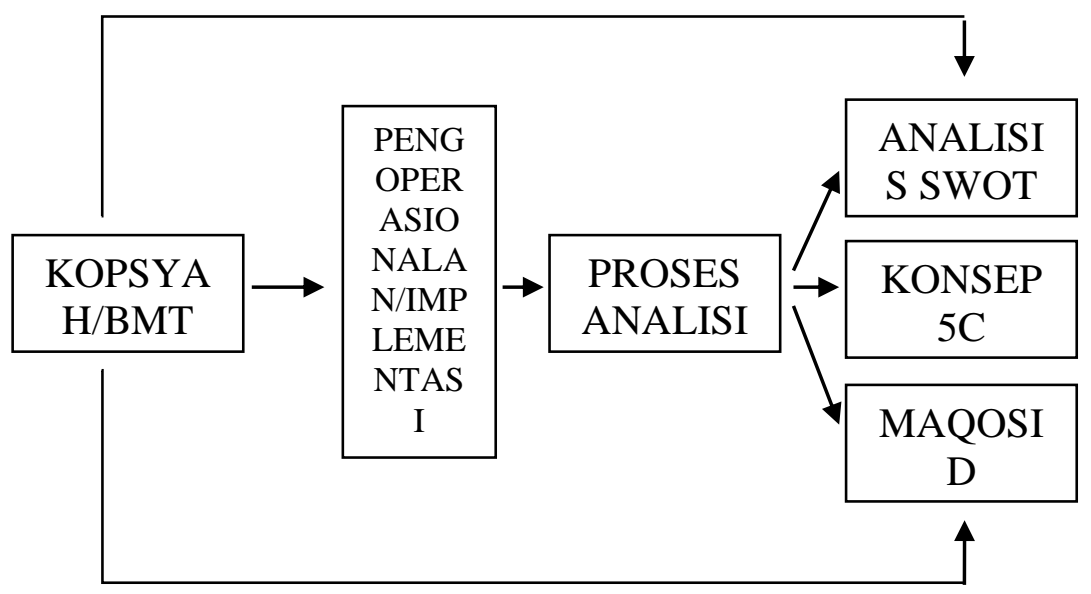


1. Analisis SWOT adalah metode perencanaan strategis yang digunakan untuk mengevaluasi kekuatan (strengths), kelemahan (weaknesses), peluang (opportunities), dan ancaman (threats) dalam suatu proyek atau suatu spekulasi bisnis. Keempat faktor itulah yang membentuk akronim SWOT (strengths, weaknesses, opportunities, dan threats). SWOT akan lebih baik dibahas dengan menggunakan tabel yang dibuat dalam kertas besar, sehingga dapat dianalisis dengan baik hubungan dari setiap aspek. Proses ini melibatkan penentuan tujuan yang spesifik dari spekulasi bisnis atau proyek dan mengidentifikasi faktor internal dan eksternal yang mendukung dan yang tidak dalam mencapai tujuan tersebut. Teknik ini dibuat oleh Albert Humphrey, yang memimpin proyek riset pada Universitas Stanford pada dasawarsa 1960-an dan 1970-andengan menggunakan data dari perusahaan-perusahaan Fortune 500. ${ }^{7}$

2. Prudent yang berarti bijaksana atau asas kehati-hatian dapat merupakan suatu konsep yang memiliki unsur sikap, prinsip, standar kebijakan, dan teknik dalam manajemen risiko perkoperasian. Koperasi syariah dalam meminimalisir risiko dan menjaga kesehatannya menerapkan prinsip kehati-hatian. Salah satu upaya yang dilakukan koperasi syariah yaitu dengan mengenal anggota (know your member principles). Koperasi syariah memiliki kegiatan untuk menyalurkan dana kepada anggota dalam bentuk pembiayaan. Setiap pembiayaan yang diberikan koperasi kepada masyarakat harus di analisis sebaik mungkin. Analisis yang dilakukan bank syariah dapat dengan menggunakan prinsip 5C.

3. Tujuan dari diterapkannya prinsip 5C ini secara tidak langsung bertujuan antara anggota dengan koperasi syariah tidak menerima hasil yang tidak jelas (gharar) dan agar terjadi kerelaan antara kedua belah pihak seperti yang telah dijelaskan dalam

${ }^{7}$ https://id.wikipedia.id.org 
Al-Qur' an surat An-Nisa' ayat 29 : "Hai orang-orang yang beriman janganlah kamu memakan harta sesamamu dengan jalan yang batil, kecuali dengan jalan perniagaan yang berlaku dengan suka sama suka diantara kamu. Dan janganlah kamu membunuh dirimu; sesungguhnya Allah adalah Maha Penyayang kepadamu.”

4. Dalam hal pemberian pembiayaan, koperasi syariah sebagai lembaga keuangan harus berhati-hati dalam menyalurkan dana agar dana yang diberikan dapat bermanfaat sesuai dengan kebutuhan anggota. Layak tidaknya pemberian pembiayaan oleh koperasi syariah kepada anggota dapat dilakukan dengan analisis 5C, yaitu :

\section{a. Character}

Penilaian karakter dilakukan oleh koperasi kepada anggota untuk mengetahui itikad dari angota tersebut, baik perilaku sehari-harinya, wataknya dan sifat-sifat pribadi yang dimiliki anggota tersebut. Hal ini bertujuan untuk mengetahui apakah karakter yang dimiliki anggota tersebut memang benarbenar baik atau kurang baik. Hal tersebut juga bisa dilihat dari BI checking angota tersebut. Walaupun anggota tersebut diyakini mampu secara finansial untuk memenuhi kewajiban, namun jika anggota tersebut memiliki itikad yang kurang baik maka koperasi akan mempertimbangkan untuk pemberian pembiayaan atau bisa jadi koperasi tidak akan merealisasi pembiayaan yang diajukan.

Gambaran mengenai penilaian tentang karakter calon anggota, yaitu :

1) Memiliki riwayat hidup yang baik;

2) Verifikasi data dengan melakukan interview;

3) Meneliti reputasi calon anggota tersebut di lingkungan usahanya;

4) Bank Indonesia checking dan meminta informasi antar koperasi; 
5) Mencari informasi atau trade checking kepada asosiasi-asosiasi/mitra usaha dimana calon anggota berbisnis; dan

6) Mencari informasi tentang gaya hidup dan hobi calon nasabah/anggota ${ }^{8}$.

b. Capacity

Penilaian kemampuan nasabah untuk menjalankan usaha guna memperoleh laba yang nanti akan dapat digunakan untuk mengembalikan pembiayaan yang diberikan koperasi kepada anggota. Untuk mengukur capacity dapat dilakukan melalui berbagai pendekatan :

1) Pendekatan historis, yaitu penilaian dengan menunjukkan perkembangan usaha yang dimilikinya minimal umur usaha lebih dari 2 tahun.

2) Pendekatan profesi, yaitu penilaian latar belakang pendidikan para pengurus perusahaan. Hal ini dilakukan untuk perusahaan yang menghendaki keahlian teknologi tinggi dan profesionalisme tinggi.

3) Pendekatan yuridis, yaitu apakah calon anggota mampu dan memiliki kapasitas untuk mewakili badan usaha yang diwakilinya untuk mengadakan perjanjian pembiayaan dengan koperasi.

4) Pendekatan manajerial, yaitu menilai kemampuan dan ketrampilan anggota dalam melaksanakan tugas dan kewajiban nya memimpin perusahaan.

5) Pendekatan teknis, yaitu penilaian kemampuan anggota dalam hal mengelola faktor-faktor produksi sehingga mampu menguasai pangsa pasar yang ditargetkan oleh perusahaan ${ }^{9}$.

c. Capital

Capital digunakan untuk melihat seberapa besar penggunaan modal dalam kegiatan usahanya, apakah modal yang selama ini digunakan sesuai

\footnotetext{
${ }^{8}$ Trisadini P. Usanti dan Abd. Shomad, Transaksi Bank Syariah, Jakarta : PT. Bumi Aksara, 2013, h. 67

${ }^{9}$ Rohmatan, Analisis Implementasi Prinsip 5C dalam Upaya Pencegahan Pembiayaan Mudharabah Bermasalah di KSPPS BMT UMMAT SEJAHTERA (BUS) Cabang Cepu, 2015, h. 18.
} 


\section{Jurnal Asy-Syukriyyah}

dengan laporan keuangan yang diberikan calon anggota kepada koperasi syariah atau justru antara modal yang ada dengan penggunaan modal untuk pengelolaan usaha tidak sesuai atau terdapat kejanggalan. Dalam penilaian capital koperasi syariah selain melihat dari laporan keuangan calon anggota, juga harus dilihat dari sumber modal yang didapat oleh calon anggota ${ }^{10}$.

\section{d. Collateral}

Collateral atau yang sering disebut dengan jaminan adalah barang atau sesuatu yang berharga dan memiliki nilai untuk dijadikan sebagai penjamin bagi calon angota untuk mengajukan pembiayaan kepada koperasi syariah. Jaminan yang diberikan calon anggota kepada koperasi syariah biasanya berupa tanah, bangunan, benda bergerak (mobil, motor), dan barang atau apapun yang sekiranya dapat disetujui oleh pihak analis pembiayaan dan dapat dijadikan sebagai jaminan.

\section{e. Condition of Economic}

Penilaian kondisi usaha dapat dipengaruhi oleh situasi sosial dan ekonomi yang ada. Tidak hanya pada sektor yang akan dibiayai saja, melainkan pada sektor ekonomi menyeluruh yang dalam hal ini juga menjadi bagian dari penentuan kondisi usaha calon angota yang akan dibiayai. Hal ini dapat meliputi analisis terhadap variabel ekonomi mikro. Pada saat ekonomi mengalami penurunan atau dalam keadaan krisis, koperasi syariah akan lebih berhati-hati lagi dalam memberikan pembiayaan, hal ini dilakukan karena koperasi syariah ingin menilai beberapa kondisi yang memang dijadikan sebagai acuan dalam penilaian condition of economic (kondisi ekonomi calon anggota).

\footnotetext{
${ }^{10}$ Thamrin Abdullah dan Francis Tantri, Bank dan Lembaga Keuangan, Jakarta : PT. RajaGrafindo Persada, 2014, h. 173.
} 


\section{Maqosid Syariah}

Manajemen resiko syariah berikutnya adalah dengan mengaplikasikan prinsipprinsip yang terkandung dalam konsep Maqosid Syariah (tujuan-tujuan syariah). Istilah maqashid al-syari’ah dipopulerkan oleh Abu Ishak Asy-Syatibi yang tertuang dalam karyanya Muwaffaqat sebagaimana dalam ungkapannya adalah "Sesungguhnya syariat itu diturunkan untuk merealisasikan maksud Allah dalam mewujudkan kemashlahatan diniyah dan duniawiyah secara bersama-sama”. Berikut konsep prinsip maqosid syariah:

a. akidah, keimanan dan ketakwaan (hifzu ad-dien), bertujuan menjaga kemurnian akidah

b. intelek (hifzu al- 'aql), bertujuan menjaga kesehatan akal

c. keturunan (nasl), bertujuan menjaga keturunan

d. jiwa (hifzu an-nafs), bertujuan menjaga keselamatan jiwa dan

e. harta benda (hifzu al-mal), bertujuan menjaga keselamatan harta/kekayaan.

\section{Implementasi Manajemen Resiko Koperasi Syariah}

\section{a. Risiko Pembiayaan/Kredit}

Pembiayaan merupakan detak nadinya Koperasi dengan jenis usaha simpam pinjam, termasuk didalamnya KSPPS(Koperasi Syariah). Para analis di Koperasi kerap kali di juluki sebagai ahli nujum. Hal ini dikarenakan dalam melakukan proses kelayakan tidak menggunakan BI Cheking(pemerikaan historis, kualitas kredit/pinjaman), karena memamang koperasi belum memiliki otoritas SID(Sistem Informasi Debitur) dari OJK. Sehingga diperlukan kecermatan(Prudent) tingkat tinggi. Dalam hal menekan resiko pembiayaan maka dapat dilakukan usaha sebagai berikut:

b. Menerapkan analisis 5C dengan penuh cermat, misalnya dalam hal Character Koperasi Syariah harus memahami bagaimana respon calon anggota saat memberikan informasi, apakah sesuai dengan yang tertera pada Surat Permohonan 


\section{Jurnal Asy-Syukriyyah}

Pembiayaan, kemudian juga kepaduan antara anggota dengan pasangannya(suami/istri), juga yang tidak kalah penting ialah mendalami profile calon anggota kepada masyarakat sekitar rumahnya. Dalam hal Capital analis koperasi syariah harus memastikan bahwa permodalan yang dimiliki oleh calon anggota $>8 \%$ sesuai standard BI dan bersumber dari yang halal. Dalam hal Condition, apakah lokasi usaha berada dilokasi yang strategis, ramai dan tidak berada di zona terlarang, seperti diatas trotoar atau ilegal, juga berkas administrative diri maupun usaha. Dalam hal Collateral analis harus mampu menilai secara cermat nilai intrinsic dari barang/asset yang dijaminkan mampu mengcover pembiayaan apa tidak? diupayakan diatas dari plafond pembiayaan, serta mengecek bukti kepemilikan(legalitasnya). Dalam hal Capacity analis harus cermat menilai kemampuan pemohon(anggota) dalam membayar angsuran, dengan cara sebagai berikut:

Menghitung pendapatan bersih (Net Profit/Income);

NPI $=($ Profit Bruto - Cost Bruto $) \times 70 \%$

Kemudian Plafond $\leq 70 \%$ NPI atau 35\% dari takehomepay apabila pemohon berprofesi sebagai karyawan. Namun yang harus benar-benar dicermati ialah sumber pendapatan real dengan total costnya.

c. Menyertakan jaminan menjadi keharusan menurut Syariah apabila dikhawatirkan menimbulkan potensi kerugian dan untuk menjaga harta(hifzul maal) anggota kreditor(investor/shohibul maal). Dengan menyertakan jaminan dapat menjaga kualitas pembiayaan dan menekan timbulnya lost asset, serta menekan rasio pembiayaan beresiko.

d. Risiko Likuiditas

Kemampuan Koperasi Syariah untuk dapat melakukan pembayaran terhadap kewajiban-kewajiban jangka pendek yang jatuh tempo merupakan risiko likuiditas yang harus selalu terus menerus dimonitor dan dicermati. Kewajiban jangka pendek 
adalah kewajiban-kewajiban yang jatuh tempo kurang dari atau sama dengan 12 bulan. Impelementasinya sebagai berikut;

1) Dengan melakukan perencanaan arus kas, dengan memperhatikan kualitas collection(tagihan) dan potensi funding secara disiplin,

2) Bekerjasama (kemitraan) dengan lembaga penjaminan pembiayaan syariah(kafil), sehingga apabila pemohon/anggota gagal bayar maka likuiditas koperasi tetap terjaga

e. Risiko Pasar

Risiko pasar memang sangat kompleks, tidak bisa dibahas hanya parsial saja namun harus menyeluruh. Pasar yang dimaksud disini adalah pasar konvensional, yang menjadi media tumbuh dan mekarnya koperasi. Risiko pasar bisa cukup bermasalah jika usaha anngota bermasalah dengan kondisi pasar yang kurang menguntungkan sehingga pembayaran angsuran bisa menjadi tidak lancar. Adapun upaya yang dapat dilakukan berdasarkan empiris diantaranya sebagai berikut:

1) Mengetahui secara detail Condition, keadaan Pasar dari berbagai aspek diantranya factor keamanan lingkungan pasar baik untuk pembeli maupun pedagang apakah terbebas dari premanisme. Keramaian dan kepadatan pengunjung, apabila pasar tersebut ramai dikunjungi setiap hari dan sampai diatas pukul 12:00 maka pasar tersebut dapat dikategorikan sebagai pasar yang potensial. Legalitas/administrasi pengelolaan pasar dan mekanisme sewa/kepemilikan kios atau lapak juga harus benar-benar diperhatikan agar terhidar dari sanksi hukum, seperti penertiban oleh pihak trantib maupun lainnya. Mengetahui adakah rencana jangka panjang dari pengelola pasar juga harus diperhatikan untuk mengukur keberlangsungan usaha anggota yang berdagang di pasar tersebut.

2) Mengetahui secara detail Competitor yang ada didalam pasar tersebut mulai dari jumlah Lembaga Keuangan/Perorangan yang beredar juga kapasitas dari masing-masing competitor. 


\section{Jurnal Asy-Syukriyyah}

3) Mekanisme jual-beli atau transaksi yang dilakukan para pedagang terhadap para pembeli sesuai dengan prinsip-prinsip syariah. Mengetahui kebutuhan utama/dominan para pedagang maupun pembeli itu apa? terhindar dari resiko material maupun dosa dan memperoleh keuntungan yang diharapkan tentunya.

f. Risiko Nilai Margin

Menentukan nilai margin menjadi penting diperhatikan oleh koperasi syariah. Hal ini bertujuan agar:

1) Mampu bersaing dengan competitor

Dengan harga margin/bagi hasil yang kompetitif diharapkan menciptakan persaingan yang sehat dan kreatifitas pada koperasi dan upaya menjaga loyalitas anggota yang sudah existing. Dalam hal pengimplementasiannya koperasi syariah harus memperhatikan beberapa hal:

1. Nilai margin pasar/competitor, haruslah kompetitif agar mampu bersaing namun juga jangan sampai terjadi unsur Ghoban (melebihi batas kewajaran harga) sehingga koperasi berpotensi mendapat cap rentenir pada masyarakat.

2. Kemampuan anggota, dengan memperhatikan kondisi maupun volume usahanya terutama pada akad yang based on nya adalah taawun margin dapat ditekan.

3. Mampu memberikan kontribusi bagi pendapatan Koperasi Syariah

Dalam menghitung nilai margin Koperasi Syariah memiliki metode, ukuran dan standar masing-masing. Biasanya dipengaruhi oleh besarnya nisbah bagi hasil dengan shohibul maal(investor), harga pasaran barang, proyeksi keuntungan dan sebagainya.

g. Risiko Organisasi

Organisasi Koperasi syariah harus diisi oleh orang-orang yang profesinal dna berintgritas(amanah). Mulai dari top manajemen, yaitu pengurus,pengawas dan manajer sampai dengan level bawah semisal office boy. Ditemukan beberapa kasus 


\section{Jurnal Asy-Syukriyyah}

koperasi syariah yang bermasalah itu disebabkan oleh tidak berjalannya fungsi organisasi dikarenakan kualitas Sumber Daya Insaninya yang tidak kompeten dan amanah. Dalam pengelolannya tidak memiliki aturan mapun SOP/SOM yang jelas. Dalam hal implementasi resiko syariah kita dapat merujuk sabda rasulullah "apabila suatu perkara diserahkan kepada ahlinya maka tunggulah kehancurannya”. Karena itu didalam proses rekrutmen pengurus maupun pengelola harus benar-benar cermat. Langkah berikutnya adalah upgreading skill dan menumbuhkan rasa ketauhidan kepada Allah SWT agar senantiasa mawas diri pengurus dan pengelola secara rutin dan berorientasi pada peningkatan kinerja.

h. Risiko Solvabilitas

Risiko Solvabilitas dianalisa oleh Pengawas maupun manajer. Merupakan bagian dari upaya maqosid syariah, yaitu hifzul maal dalam hal ini dapat diketahui melalui dua metode penghitungan;

1) $\operatorname{DAR}($ Debt to Asset Ratio) untuk mengetahui coverage Aset Koperasi terhadap hutang dengan cara membagi antara total hutang dengan Aset dikalikan 100\%. Koperasi Syariah yang baik DAR-nya $<50 \%$. Hal ini dapat terjadi apabila anggota koperasi berkontribusi aktif dalam mendanai operasional koperasi.

2) DER (Debt to Equity Ratio) untuk mengetahui coverage Modal Koperasi terhadap hutang dengan cara membagi antara total hutang dengan modal dikalikan 100\%. Semakin kecil DER-nya semakin baik kondisi koperasi.

\section{i. Risiko Operasional}

Risiko operasional Koperasi syariah yang dimasud disini adalah berkaitan dalam operasional rutinitas/harian. Seperti salah input nominal, salah input rekening, salah input databased anggota, penyelewangan penggunaan dana/pembiayaan oleh anggota maupun staf dan sebagainya. Untuk meminimalisir hal tersebut maka fungsi pengawasan harus ditingkatkan melalui bebrapa upaya sebagai berikut: 


\section{Jurnal Asy-Syukriyyah}

1) Pengecekan rutin bukti fisik perekaman simpanan (buku tabungan) maupun pembiayaan (buku angsuran) anggota.

2) Pemberian cuti kepada staf

3) Rolling posisi maupun pasar binaan

4) Aturan Reward \& Punishman

5) Penyuluhan kepada Anggota

j. Risiko Berdasar Kapital

Modal dalam koperasi syariah sama halnya seperti koperasi pada umumnya, yaitu simpanan pokok, simpanan wajib, cadangan dan hibah. Dalam menghitung modal koperasi adalah dengan membagi antara modal tertimbang dengan aktiva produktif tertimbang. Standar permodalan koperasi merujuk pada permodalan perbankan yaitu $8 \%$. Implementasi risiko permodalan pada koperasi syariah diantaranya:

1) Membuat pencadangan risiko terhadap aktiva produktif

2) Membuat batasan risiko bisnis pada aktiva produktif

3) Meningkatkan porsi modal dari pendistribusian SHU

4) Melakukan penjaminan terhadap aktiva produktif pada lembaga penjaminan syariah

k. Risiko Hukum

Risiko hukum dapat terjadi terhadap implikasi yang timbul dari perjanjian atau kesepakatan dengan beberapa pihak bisa dari anggota atau mitra. Wanprestasi dari salah satu pihak yang membuat kesepakatan menimbulkan potensi terhadap counterparty untuk melakukan tindakan hukum. Tindakan hukum dalam sengketa keuangan syariah dapat berupa perdata yang dapat dinaikkan tingkatannya menjadi gugatan pidana apabila unsur-unsur untuk terjadinya pidana telah terpenuhi. Permasalahan yang timbul bisa terjadi karena perjanjian pembiayaan dengan pihak luar, perjanjian pembiayaan dengan anggota, perjanjian dengan penyedia logistik/vendor inventaris, perjanjian sewa bangunan, atau perjanjian lain yang mungkin akan diadakan oleh lembaga kepada pihak lain. Ada kaidah Islam yang 


\section{Jurnal Asy-Syukriyyah}

berbunyi addororu yuzalu bahwa bahaya itu harus dihilangkan, dengan memperhatikan aspek legal berarti kita berusaha mencegah timbulnya bahaya, dalam hal ini sengketa hokum. Maka untuk menghindari risiko hukum koperasi syariah dapat melakukan upaya sebagai berikut:

1) Melakukan screaning sejak awal terhadap calon anggota debitor terutama dalam character dan collateral.

2) Dalam hal collateral pastikan bahwa barang yang dijaminkan adalah milik pribadi anggota atau telah dikuasai secara penuh, dapat dibuktikan dengan bukti kepemilikan dan sebagainya. Jika barang yang dijaminkan milik oranglain harus dibuatkan surat pernyataan dari sipemilik secara langsung dihadapan pihak koperasi dengan dibubuhi materai.

3) Dalam hal perikatan kontrak perjanjian harus dibuat secara jelas, terang, rinci, mudah dipahami. Dapat menyerupai drafter kontrak di perbankan syariah sehingga peluang risiko hukum dapat diminimalisir.

1. Kepatuhan prinsip syariah

Dalam melakukakan manajemen resiko syariah juga harus terpenuhi kepatuhan prinsip-prinsip syariah, diantaranya:

1) harus jelas akad yang digunakan

2) terpenuhi rukun dan syaratnya

3) tidak mengandung unsur judi(maysir), bunga(riba), ketidakjelasan(ghoror), kerusakan(dhoror/bathil),

4) memiliki Dewan Pengawas Syariah sesuai amanat PERMENKOP NOMOR 16 /Per/M.KUKM/IX/2015 Pasal 14 tentang Dewan Pengawas Syariah. 


\section{Jurnal Asy-Syukriyyah}

\section{Kesimpulan}

Terdapat berbagai macam resiko dalam operasional koperasi syariah seperti resiko pembiayaan, resiko likuiditas, nilai margin, organisasi, solvabilitas , operasional, capital, resiko hokum dan kepatuhan terhadap prinsip-prinsip syariah.

Kesemuanya harus di manage agar resiko dapat ditekan seminimal mungkin agar rencana dan target yang telah dicanangkan dapat terealisasi sehingga menghasilkan kemaslahatan. Didalam implementasi manajemen resiko dalam koperasi syariah dapat mengkombinasikan antara analisis SWOT, konsep prudential dengan 5C dan Maqosid Syariah.

Abu Ishak Asy-Syatibi yang tertuang dalam karyanya Muwaffaqat sebagaimana dalam ungkapannya adalah: "Sesungguhnya syariat itu diturunkan untuk merealisasikan maksud Allah dalam mewujudkan kemashlahatan diniyah dan duniawiyah secara bersama-sama". Beliau telah merumuskan tentang mqosid syariah(tujuan syariah); untuk menjaga akidah, menjaga akal, menjaga keturunan, menjaga jiwa dan menjaga harta.

Kemudian diimplementasikan dalam manajemen resiko syariah pada operasional koperasi syariah serta merujuk pada PERMENKOP NOMOR 16 /Per/M.KUKM/IX/2015. Berdasarkan empiric hal ini mampu menekan timbulnya resiko pada koperasi syariah.

Pada prinsipnya setiap aktifitas bisnis itu memliki resiko, namun resiko dapat kita minimalisir sampai pada titik terendah apabila kita lakukan dengan cara yang tepat dan sesuai syariah. 


\section{DAFTAR PUSTAKA}

Abdullah.Thamrin. Francis Tantri,2014.Bank dan Lembaga Keuangan, Jakarta : PT. RajaGrafindo Persada

Barret.Richard. 2003.Vocational Business: Training, Developing and Motivating People

Buchori. Nur s.2012. Koperasi Syariah: Teori dan Praktik. Tangerang Selatan: Pusat Aufa Media

Deputi Bidang Pembiayaan.2015. Penyempurnaan Pedoman Standar Operasional Manajemen KJKS/UJKS koperasi. Kementrian Koperasi dan Usaha Kecil Menengah Republik Indonesia

Griffin, R. 2006. Business, 8th Edition. NJ: Prentice Hall.

P.Trisadini. Usanti. Abd. Shomad.2013. Transaksi Bank Syariah, Jakarta : PT. Bumi Aksara

Rohmatan,2015. Analisis Implementasi Prinsip 5C dalam Upaya Pencegahan Pembiayaan Mudharabah Bermasalah di KSPPS BMT UMMAT SEJAHTERA (BUS) Cabang Серu. 